ISSN No:-2456-2165

\title{
Implementing a Work Program Monitoring Information System (Case Study at PT Telkom Tbk)
}

\author{
Nanang Sopandi \\ Student of Information System Program, \\ Mercu Buana University, Jakarta, Indonesia
}

\begin{abstract}
This research was conducted by purposed to gained knowledge regarding process of implementing the work programs which carried out by PT. Telkom, especially at Network Division of Central Jakarta area around these days. while Analyze these work program system and create WEB-based work program to monitoring system according to company requirements and regulations. PT. Telkom, especially Network Division of Central Jakarta area, which engaged in telecommunications and has the main duty as operation and maintenance of equipment that owned by PT. Telkom, especially Network Division at Central Jakarta area, so it could keep the assets owned by company always operating normally. According to research that carried out by employees itself, there are so many problems in creating work programs cause it was still manual, Assistant Manager of Network Area were difficulty to monitoring the development of work programs and report the results aswell it was because there has no integration in one application system, Analysis and this pattern of information system by object-oriented methods with UML notations. With web-based work program monitoring information system, it was expected that it could be a solution to sort of problems that faced in process of implementing work programs.
\end{abstract}

Keywords:- Research, Monitoring, Maintenance, Information Systems, Web.

\section{INTRODUCTION}

\section{A. Background of Problems}

In these current era of globalization, the development of information technology greatly affects to development of company organizations, where information technology is very needed to compete and create a business which could run smoothly, improve performance as well as compete globally, the ability to compete and improve business that running well and improving performance is necessary to anticipate the increasingly of fierce global competition and also to anticipate the gaps in development of information system technology.

The monitoring information system is an application which designed to find out those modify which occur during the changes in variables continuously within a specified period of time. Monitoring information systems use to analyze and seen to those factors that cause the

\author{
Nia Rahma Kurnianda \\ Lecturer of Information System Program \\ Mercu Buana University, Jakarta, Indonesia
}

changes and movements from these variables, then by monitoring information system the dissemination of information needed and it will improve quality, effectiveness and efficiency at work program management could be achieved.

PT Telkom, Tbk is the only state-owned telecommunication company and the largest telecommunication and network service provider in Indonesia. Telkom were also provides various services in the fields of information, media and edutainment, included cloud-based and server-based managed services, e-Payment and IT enabler, e-Commerce and other portal services.

Gambir Network Area is one of sub-units of Netre Jakarta which is part of division at PT Telkom Tbk. To carry out its operations and maintenance, for each Assistant Manager of division unit creates and prepares a schedule for carrying out operations and maintenance in form of work program, a work program was to created and arranged by each Assistant Manager from each division unit and reported to their Area Manager. In its implementation, there had stumble in monitoring the development of work programs which running, including Assistant Manager and Area network manager had difficultness to monitor the development of work programs because there are so many work programs that have been made which not optimal and the results of its reports were less effective and efficient and lack of information obtained by staff due to the absence of integrated data in one application system and also the lack of utilization from existing information systems.

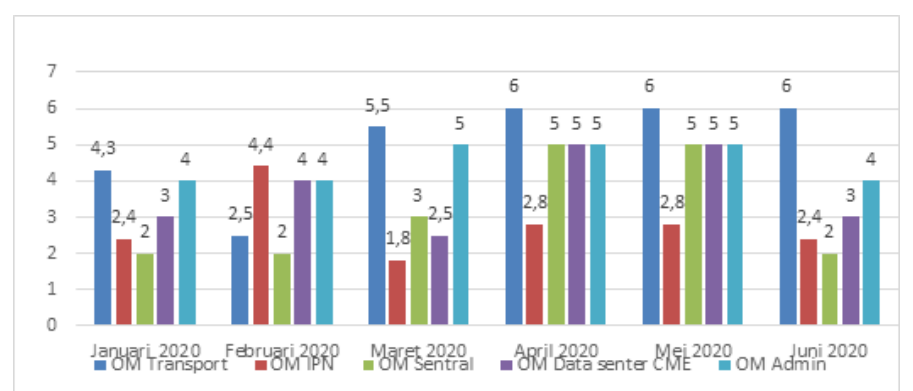

Fig 1:- Consistency Data of Network Area Division's Work Program

Based on these problem background and several problems that occur, the role of information technology could be utilized and based on explanation of current problems in Network Area Division, the authors were 
interested in carried out the research with tittle "Implementing a Work Program Monitoring Information System (Case Study: PT TELKOM Tbk)" who could manage data automatically and online as well as provide information for monitoring, manage work programs and make it easier to all staff in implementing work programs that have been compiled with hoped that it would provide the solutions to those existing problems.

\section{B. Research Purposes}

The purposed that need to be achieved in these research as follows:

$>$ Produced a good design of work program monitoring information system that capable to manage operational data and Network Area Maintenance so it could simplify the implementation process.

$>$ Creating a WEB-based information system that could solve problems both of employee side and company side.

$>$ Simplify the current process of work program monitoring.

$>$ Increase the existence and effectiveness of data and information storage media because the design of this system was made for website-based applications that could be accessed in everywhere.

$>$ Make it easier for employees to carry out these work programs, especially for operations and maintenance, because they are well scheduled then they could be carried out and finished on time.

\section{LITERATURE REVIEW}

\section{A. Work Program}

The work program is an important component for organization in achieving its goals. Work program is a plan of work activities that have been designed and mutually agreed upon and implemented within a certain period of time. Work program should be directed in a way, because it will be guide for organization to achieve its goals. Beside that, work program could appears as benchmark for achieving targets when doing work, then results will be evaluated at the end of the management.

\section{B. Information Systems}

According to Sutabri (2012: 38), the information system is a system within organization that meets the needs of daily transaction processing, supports the operations, and has managerial way with strategic activities from organization in order to provide the reports that needed from outsiders. Information systems depend on human resources, hardware, software, data and networks to carry out input, processing, output, storage and control activities that could transform data sources into information products.

\section{Monitoring}

Monitoring is the process of collecting and analyzing information based on indicators which set systematically and continuously on activities / programs so corrective actions could be taken for further improvement of the program / activity. Monitoring will provide information about the status and tendency if the measurements and evaluations are completed over and over from time to time, monitoring is generally carried out for detailed purpose, to check against the following process objects or evaluate the conditions or progress towards management results on impact of various actions such as to keeping the current management (Gentisya, 2014).

\section{Maintenance}

Maintenance Management is managed all the maintenance work through process of planning, organizing and controlling the maintenance operations to provide information regarding industrial facilities. (Gunawan, et al, 2017).

\section{E. Black Box Testing}

Black box testing is an evaluating of software quality which has focuses on software functionality. Black box testing aims to discover incorrect functions, interface errors, data structure errors, performance errors, initialization errors and terminations. (Setiyani, 2019).

\section{F. Waterfall Development Method}

According to Darmawati \& Noprisson (2018) Waterfall method is a software process model that takes basic process activities such as specification, development, validation and evolution by presented them as different process phases such as requirements analysis and definition.

\section{METHODELOGY}

This research will be conducted at STO Gambir Office of PT. TELKOM Network Area Division on Center of Jakarta. Hardware and software tools to support this research include supporting hardware / laptops (Intel $®$ Core ${ }^{\mathrm{TM}}$ i3-6006U Processor, 2.0GHz; 4 Gb RAM DDR 4; 500 GB Harddisk) and supporting software (Google Chrome; Balsamiq_Mockups; StarUML; Draw.io; Microsoft Office).

The methods used in this research including Fishbone Diagram problem analysis, analysis methods that used problem solving approaches by literature study methods from prior research, input and output analysis, business process analysis, activity diagrams, identification of functional and non-functional system requirements, making Use Case diagrams as well creating Use Case diagrams descriptions.

Design method used by the writer was Object Oriented Design which includes domain class design, database specifications, input design and user interface output, class diagram design and Squance Diagram design.

The system development method used a method which taken from the Waterfall method that has been described in prior chapter. 


\section{RESULT AND DISCUSSION}

\section{A. Analysis of the Current System}

These current work program system still uses manual system starting from work program planning that will be proposed from each employee unit to the Assistant Manager unit and still made by Excel Forms to be submitted to the manager. In implementation of work program at Jakarta Network Area Division, the employees who carry out Operations and Maintenance, there are still many targets which have not been achieved or completed according to the set schedule and also its implementation many employees that carry out operations and maintenance not according to predetermined schedule so it wont stumbling the operational work.

\section{B. Identification of Functional and Non-Functional Needs Analysis}

The results from these analysis monitoring work programs information system at PT. Telkom Tbk Network Area Division as follows:

\begin{tabular}{|c|c|c|c|}
\hline No. & Needs & Requirement Details & Actor \\
\hline 1 & $\begin{array}{l}\text { Submission of work } \\
\text { programs, implementation } \\
\text { of work programs, reporting } \\
\text { work programs }\end{array}$ & $\begin{array}{l}\text { a. User interface of work program submission, implementation } \\
\text { and report. } \\
\text { b. CRUD checklist method } \\
\text { c. Employee table, assistant manager table, manager table, work } \\
\text { program table }\end{array}$ & $\begin{array}{l}\text { Employee, } \\
\text { Assistant Manager, } \\
\text { Managar }\end{array}$ \\
\hline 2 & $\begin{array}{l}\text { Add/change/delete data for } \\
\text { submission, implementation, } \\
\text { work program report. }\end{array}$ & $\begin{array}{l}\text { a. User interface of work program submission, implementation } \\
\text { and report. } \\
\text { b. CRUD checklist method } \\
\text { c. Administration table }\end{array}$ & Administration \\
\hline 3 & Checklist implementation & $\begin{array}{l}\text { a. User Interface, Implementation, filling in the checklist } \\
\text { b. CRUD checklist method. } \\
\text { c. }\end{array}$ & Employee \\
\hline 4 & $\begin{array}{c}\text { Potential data validation and } \\
\text { reports }\end{array}$ & $\begin{array}{l}\text { a. User Interface, Validation and potential data reports } \\
\text { b. } \\
\text { c. }\end{array}$ & Employee \\
\hline 5 & Handling Device Crashes & $\begin{array}{l}\text { a. User Interface, Implementation, filling in the checklist } \\
\text { b. CRUD Checklist method } \\
\text { c. Employee table, checklist table }\end{array}$ & Employee \\
\hline 6 & Work Order Creation & $\begin{array}{l}\text { a. User Interface, Implementation, checklist filling } \\
\text { b. CRUD Checklist method } \\
\text { c. Employee table, checklist table }\end{array}$ & Employee \\
\hline 7 & $\begin{array}{l}\text { Submission of calibration } \\
\text { for measuring instruments }\end{array}$ & $\begin{array}{l}\text { a. User Interface, Implementation, filling the checklist } \\
\text { b. CRUD Checklist method } \\
\text { c. Employee table, checklist table }\end{array}$ & Employee \\
\hline 8 & The Official report & $\begin{array}{l}\text { a. User Interface, Implementation, filling the checklist } \\
\text { b. CRUD Checklist method } \\
\text { c. Employee table, checklist table }\end{array}$ & Employee \\
\hline 9 & Submission of Budget Plan & $\begin{array}{l}\text { a. User Interface, Implementation, filling the checklist } \\
\text { b. CRUD Checklist method } \\
\text { c. Employee table, checklist table }\end{array}$ & Employee \\
\hline 10 & SIMARU creation & $\begin{array}{l}\text { a. User Interface, Implementation, filling the checklist } \\
\text { b. CRUD Checklist method } \\
\text { c. Employee table, checklist table }\end{array}$ & Employee \\
\hline
\end{tabular}

Table 1:- Identification of Needs Analysis 


\section{Piece Analysis and Cause and Effect Analysis}

The results of observations and interviews with employees, assistant managers in Central Jakarta Network
Area Manager could identify some of the problems and their causes.

\begin{tabular}{|c|c|}
\hline \multicolumn{2}{|r|}{ Performance } \\
\hline Problem & $\begin{array}{c}\text { Time process which needed to find, create and monitor work programs that takes long time and often constrained in } \\
\text { implementation of work programs and it reports. }\end{array}$ \\
\hline Cause & $\begin{array}{l}\text { Data that presented are not combined and still separate in each unit so it would takes a long time to combine, The data } \\
\text { storage is still in each unit then it would make difficult to monitor as the data created still as it is. }\end{array}$ \\
\hline \multicolumn{2}{|r|}{ Information } \\
\hline Problem & $\begin{array}{l}\text { Because there are so many work programs that should be made and submitted from each unit, so each unit need to } \\
\text { print each work program that was made. In the end, the costs incurred are relatively large because they have to make } \\
\text { work program forms and others so it wasted lots of papers. }\end{array}$ \\
\hline Cause & The use of paper is a priority in submission, implementation and reporting of each unit's work program \\
\hline \multicolumn{2}{|r|}{ Economy } \\
\hline Problem & $\begin{array}{l}\text { Because there are so many work programs that should be made and submitted from each unit, so each unit need to } \\
\text { print each work program that was made. At the end, the costs which incurred were relatively large because they have } \\
\text { to make work program forms and others so it wasted lots of papers. }\end{array}$ \\
\hline Cause & The use of paper is a priority in submission, implementation and reporting of each unit's work program \\
\hline \multicolumn{2}{|r|}{ Control } \\
\hline Problem & $\begin{array}{l}\text { Data of implementation results from work programs which not monitored can not be directly reports to the manager, } \\
\text { as for the implementation of work programs and reports were often not according to time }\end{array}$ \\
\hline Cause & $\begin{array}{l}\text { In inputting the submission data, implementation and work program reports by each unit are input into worksheet of } \\
\text { each unit }\end{array}$ \\
\hline \multicolumn{2}{|r|}{ Eficiency } \\
\hline Problem & Preparation, submission of implementation and project reports took long time \\
\hline Cause & $\begin{array}{c}\text { Because all data that will be created in form of a worksheet when submitting, executing and reporting should need to } \\
\text { input the same data repeatedly }\end{array}$ \\
\hline \multicolumn{2}{|r|}{ Services } \\
\hline Problem & $\begin{array}{c}\text { It is difficult for managers, Asst. Manager and employees to created documentation and get information about work } \\
\text { programs because they have to find data that takes a long time. }\end{array}$ \\
\hline Cause & $\begin{array}{c}\text { Because in making these submissions, implementation and reporting still using a manual system and the data needed } \\
\text { to recap were the data which still submitted separately in each unit. }\end{array}$ \\
\hline
\end{tabular}

Table 2:- Analysis of Piece and Cause and Effect Analysis Performance

\section{Fishbone Diagram}

The results from identification of problems and it causes which could be described in these fishbone diagram were explained that there had connection between the problem and its causes which makes difficult for the manager at Central Jakarta Network Area to monitoring the work programs.

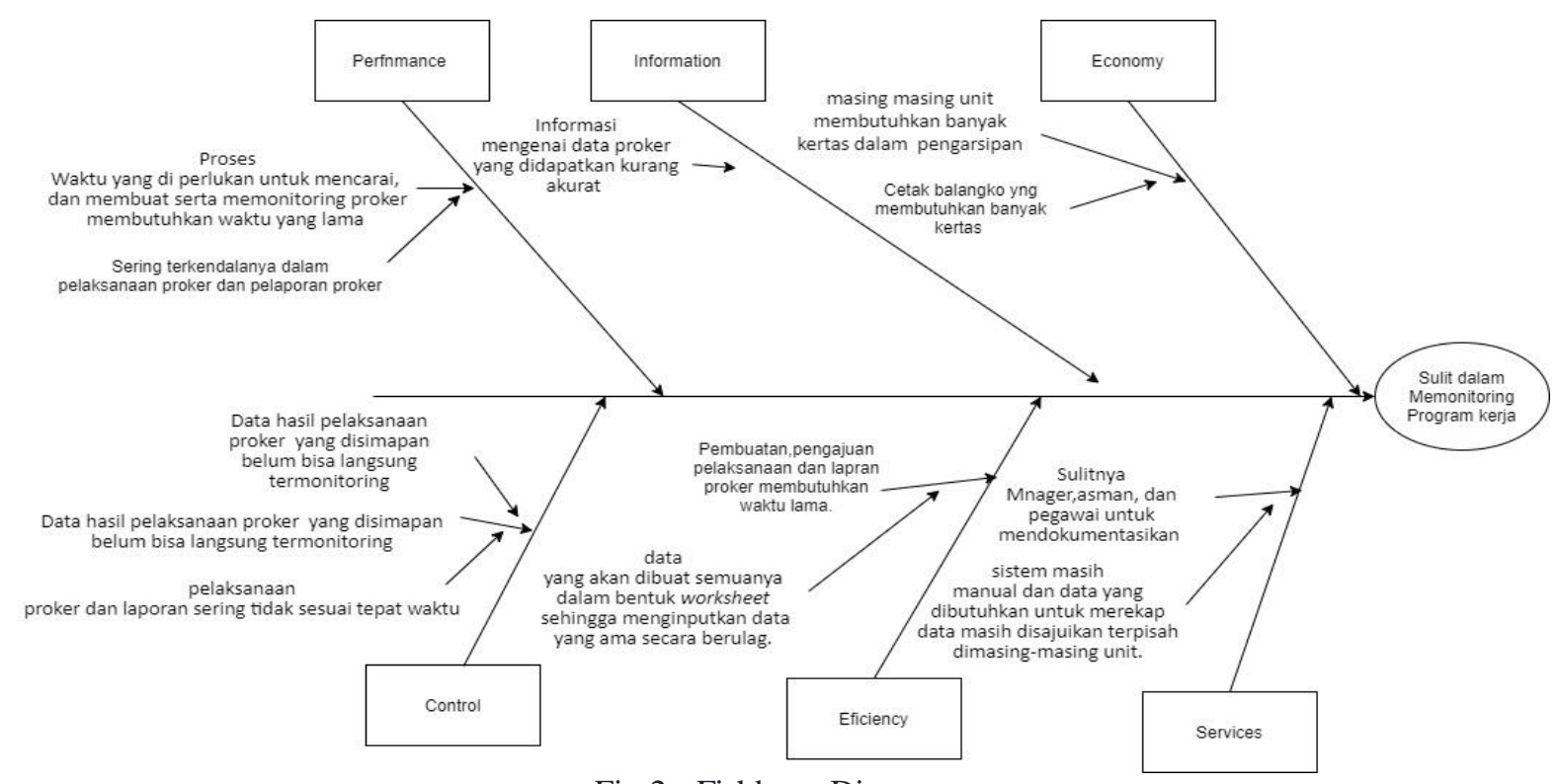

Fig 2:- Fishbone Diagram 
Solutions to these matters could be explained in table below.

\begin{tabular}{|c|c|}
\hline \multicolumn{2}{|r|}{ Performance } \\
\hline Solution & $\begin{array}{l}1 \text { The system that be created should makes an easy for managers to monitor work programs } \\
2 \text { As For Asst. Manager, it will provide convenience in creating 9and submitting work programs } \\
3 \text { As for Employees, it will provide convenience in submitting, implementing and reporting work } \\
\text { programs }\end{array}$ \\
\hline \multicolumn{2}{|r|}{ Information } \\
\hline Solution & $\begin{array}{l}\text { Monitoring those program will get easier because all data will be entered into one system so it is easy to find } \\
\text { the desired information }\end{array}$ \\
\hline \multicolumn{2}{|r|}{ Economy } \\
\hline Solution & $\begin{array}{l}\text { Providing a system design that makes it easy to create work programs and others, the processing of project } \\
\text { data and others will be carried out by system so it wont use so much paper }\end{array}$ \\
\hline \multicolumn{2}{|r|}{ Control } \\
\hline Solution & Provide a design that makes it easy to monitor work programs, implementation and reports \\
\hline \multicolumn{2}{|r|}{ Eficiency } \\
\hline Solution & $\begin{array}{l}\text { Provide a plan that results in filling out, implementing and report to those work programs so it won't take a } \\
\text { long time }\end{array}$ \\
\hline \multicolumn{2}{|r|}{ Services } \\
\hline Solution & Provides a design that can be used to monitoring programs by entering web only \\
\hline
\end{tabular}

Table 3:- Pieces of Solutions which produced

\section{E. System Planning}

In this design of work program monitoring information system at PT. TELKOM, Central Jakarta Area Witel Network Division, the author used the Unified Modeling Language (UML). UML is a programming language for information systems in making a design concept using diagrams to fixing a system that is currently running. The diagrams which created to design the system by the author such as case diagrams, activity diagrams, sequence diagrams, and class diagrams.

\section{F. Implementation Output}

The implementation of the outputs that will be produced by implementing this information system are as follows:

\begin{tabular}{|c|c|c|}
\hline No. & Case & Table \\
\hline 1 & Print Work Program Submission Data & Data_proker \\
\hline 2 & Print Work Program Consistency Report Form & Data_checklist \\
\hline 3 & Print Checklist Form Data & Data_gangguan \\
\hline 4 & Print Nuisance Form Data & Data_dapot \\
\hline 5 & Print Potential Data Validate Form Data (Dapot) & Data_workorder \\
\hline 6 & Print Work Order Form Data (WO) & Data_kalibrasi \\
\hline 7 & Print Form Data for Measuring Calibration & Data_Beritaacara \\
\hline 8 & Print Data Form Minutes (BA) & Data_rencanaanggaranbelanja \\
\hline 9 & Print Data Budgets Plan (RAB) Form & Data_Suratijinmasukruangan \\
\hline 10 & Print Data Room Entry Permit Form (SIMARU) & \\
\hline
\end{tabular}

Table 4:- Output Implementation 
G. Resume User Acceptance Test

Module Design: The role of designing work program monitoring information systems
UAT date: 10 September 2020 Participants: 7 people (6 testers, 1 operator)

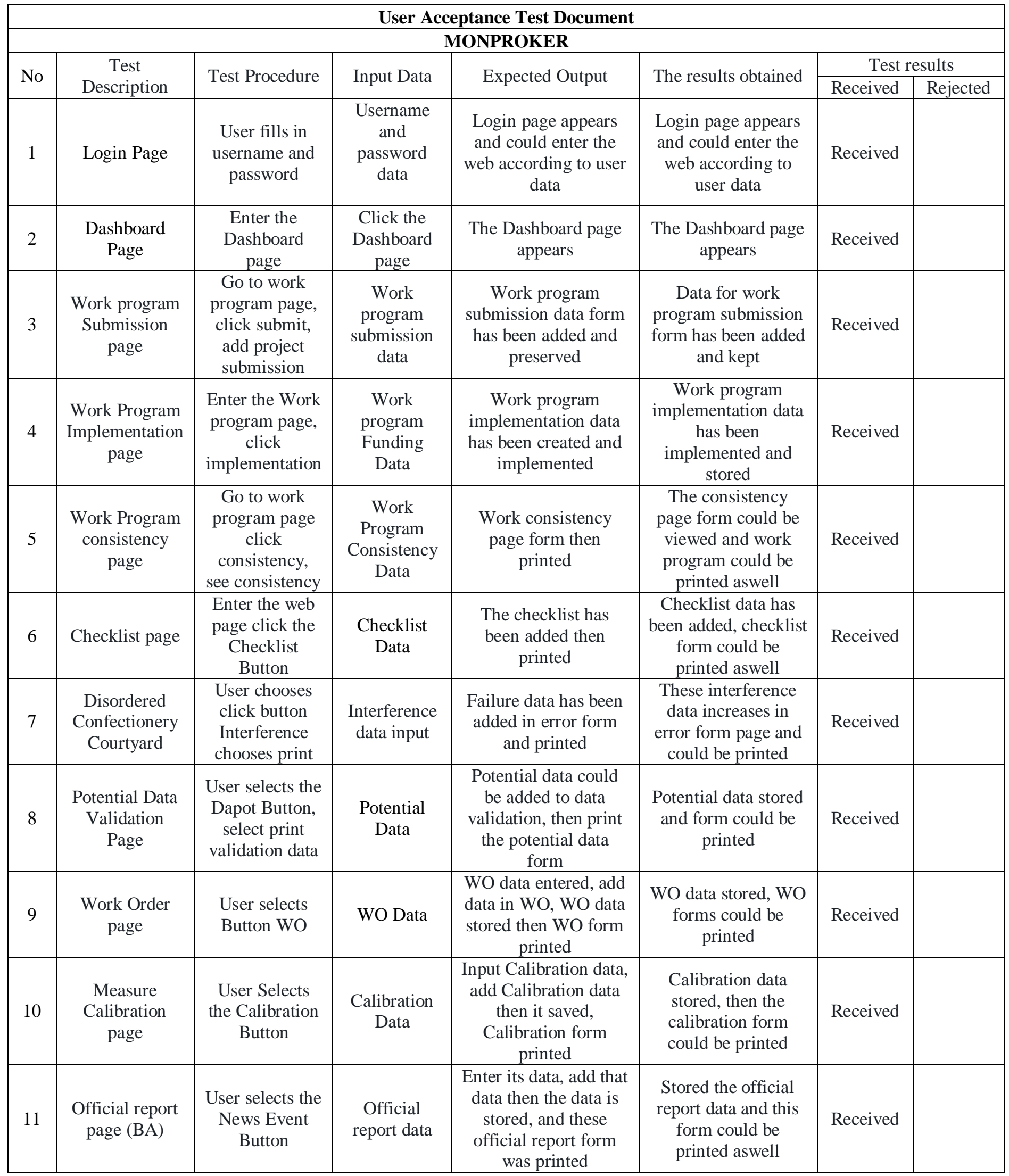




\begin{tabular}{|c|c|c|c|c|c|c|}
12 & $\begin{array}{c}\text { Budget Plan } \\
\text { page }\end{array}$ & $\begin{array}{c}\text { User selects the } \\
\text { Budget Plan } \\
\text { Button }\end{array}$ & $\begin{array}{c}\text { Budget Plan } \\
\text { Data }\end{array}$ & $\begin{array}{c}\text { Enter the BP data, } \\
\text { added BP data, the } \\
\text { budget plan data was } \\
\text { stored, the BP form } \\
\text { was printed }\end{array}$ & $\begin{array}{c}\text { The Budget plan } \\
\text { data was stored, then } \\
\text { the Budget plan form } \\
\text { was printed }\end{array}$ & Received \\
\hline 13 & $\begin{array}{c}\text { Room Entry } \\
\text { Permit page }\end{array}$ & $\begin{array}{c}\text { User selects } \\
\text { SIMARU } \\
\text { Button }\end{array}$ & $\begin{array}{c}\text { SIMARU } \\
\text { data }\end{array}$ & $\begin{array}{c}\text { Enter the data, add } \\
\text { SIMARU data, save it } \\
\text { then print SIMARU } \\
\text { forms }\end{array}$ & $\begin{array}{c}\text { SIMARU data was } \\
\text { saved and also the } \\
\text { form was printed }\end{array}$ & Received \\
\hline
\end{tabular}

Table 5:- Resume User Acceptance Test

\section{CONCLUSION AND SUGGESTION}

\section{A. Conclusion}

Based on those descriptions which has displayed above and based on the explanation which author describe in previous chapters, the authors make several the following conclusions such as:

$>$ Designing this Information System had resulted in a proposal to create Monitoring Information System for work program that could be assist and support the completion of work program which could run on time as desired.

This Information System Design had results in the pattern of information systems that are needed and very useful for companies, especially for Network Area Division that will encourage and improve the company performance in each work unit.

$>$ By this information system, you can backup the data to protect from it lost or corrupted, so it will not causing an issue in monitoring work program.

\section{B. Suggestion}

Based on these conclusions from this research, the authors could provide some suggestions and input for PT. TELKOM Central Jakarta Area especially to Network Division that could be describe as follows:

$>$ The appearance of current WEB still simple and its hoped that in future development the animation features could be added so it would improve the lack of WEB's appearance.

$>$ It was expected that the application can be seriously developed and could possible to add an employee appraisal features.

\section{REFERENCES}

[1]. Firmansyah, S. Kom, M. K. Deddy, and M. S. Si, "Layanan Kependudukan Berbasis Website," J. Lpkia, vol. 1, no. 2, pp. 1-7, 2017.

[2]. D. Akbar, Ri. P. Astuti, and B. S. Nugroho, "PERANCANGAN DAN ANALISIS MIMO MIKROSTRIP PATCH RECTANGULAR DUAL BAND ( $6 \mathrm{GHz}$ DAN $28 \mathrm{GHz}$ ) UNTUK KOMUNIKASI INDOOR," TEKTRIKA - J. Penelit. dan Pengemb. Telekomun. Kendali, Komputer, Elektr. dan Elektron., vol. 3, no. 1, p. 23, 2019.

[3]. Gentisya Tri Mardiani, "Sistem Monitoring Data Aset Dan Inventaris Pt Telkom Cianjur Berbasis Web," $J$. Ilm. Komput. dan Inform., vol. 2, no. 1, pp. 35-40, 2014.
[4]. L. Suryadi, "Rancang Bangun Sistem Informasi Monitoring Pelaksanaan Pekerjaan Studi Kasus : Suku Dinas Pekerjaan Umum Tata Air Kota Administrasi Jakarta Selatan Dengan Metodologi Berorientasi Obyek," Pros. SENTIA 2015, vol. 7, pp. C1-5, 2015.

[5]. A. Jaenudin, D. Wahyuningtyas, P. Dwi, and A. Pamungkas, "Sistem Pemantauan Dan Pemeliharaan Perangkat Teknologi Informasi Berbasis Web Pada Departemen IT PT Denso Indonesia Bekasi," $J$. Teknol. Inf., vol. 1, no. 1, pp. 119-134, 2016.

[6]. F. H. Musleh Al Hayubi, Zainal Arifin, "Sistem Informasi Pengecekan Dan Monitoring Laboratorium Komputer Di Sttnj Berbasis Android Dan Web," vol. 8, pp. 37-42, 2016.

[7]. A. S. Gunawan, A. Setiawan, and F. Legirian, "Perancangan Maintenance Management Informastion System untuk Unit Pemadam Kebakaran (Studi Kasus : PERUSAHAAN X)," J. Nas. Teknol. dan Sist. Inf., vol. 3, no. 2, pp. 219-224, 2017.

[8]. L. Setiyani, "Pengujian Sistem Informasi Inventory Pada Perusahaan Distributor Farmasi Menggunakan Metode Black Box Testing," Techno Xplore J. Ilmu Komput. dan Teknol. Inf., vol. 4, no. 1, pp. 1-9, 2019.

[9]. S. I. Darmawanti and H. Noprisson, "MONITORING PELANGGARAN SISWA ( STUDI KASUS : SMK SATRIA JAKARTA ) Pendahuluan Landasan Teori Metodologi," Ikhafi, vol. xx, no. x, pp. 26-33, 2018.

[10]. G. W. Sasmito, "Penerapan Metode Waterfall Pada Desain Sistem Informasi Geografis Industri Kabupaten Tegal," J. Inform. Pengemb. IT, vol. 2, no. 1, pp. 6-12, 2017.

[11]. T. F. Alimuddin Yasin, MZ Yumarlin, "Analisis Kebutuhan Sistem Informasi di LPK RJ-COMP Yogyakarta," Semin. Nas. Inform., vol. 1, no. 1, pp. 111-116, 2017.

[12]. D. Alan, B. Haley, and D. Wixom, Systems Analysis Design with UML Version 2.0: An Object-Oriented Approach. 2015. 